Environment Conservation Journal 15( 3) 63-69, 2014

ISSN 0972-3099 (Print) 2278-5124 (Online)

Abstracted and Indexed

\title{
Effect of temperature variations on growth, dry matter and yield of Wheat (Triticum aestivum $L$ ) under Mid Himalayan Region of Uttarakhand
}

\author{
R.G.Upadhyay $\square$ and Prakash Singh Negi
}

Received:05.04.2014

Revised: 24.08.2014

Accepted:02.10.2014

\begin{abstract}
Uttarakhand is composed, in parts, of the Himalayan mountain ranges having different altitudes and orientations. Wintertime eastward-moving low-pressure synoptic weather systems (western disturbances) are modified by these orographic barriers. Therefore, advance and proper information of maximum and minimum temperature becomes important for assessing natural hazard threats. The trend analysis for both maximum and minimum temperature using 2-year moving averages was done for the period 2003-2012. It shows moving average trends indicate that maximum temperature is decreasing over the period, while little increasing trend was observed in case of minimum temperature during the period 2003-2012. The experiment was conducted in a two factors randomized block design (RBD) with four replications, three dates of sowing and two varieties viz. UP - 1109 and Sonalika (RR-21) recommended for different sowing environments. Seasonal trends of maximum temperature indicate decreasing trend throughout the year, while minimum temperature shows decreasing trend during rainy season whereas during other three seasons the trend was reverse. The maximum temperature during winter seasons was increasing during the first and last pentad. In general the maximum temperature has shown increasing trend during the last pentad in all the four seasons. Temperature play very important role in flowering and maturity of crops as well as quality parameters also. Due to increasing temperature at the time of vegetative stages, early flowering and maturity has been observed in wheat.
\end{abstract}

Keywords: dry matter, Himalayan region, temperature, variation

\section{Introduction}

Over the hilly areas of the western Himalayas, such as Jammu and Kashmir, Laddakh, Himachal Pradesh and Uttarakhand, knowledge of maximum and minimum temperatures during the winter months is very important for assessing human comfort, cold weather conditions, avalanche release, state of snow and frost. Maximum and minimum temperatures at a specific location depend upon the season, synoptic conditions and local parameters, including orography, land-use and vegetation cover. It is difficult to predict locationspecific surface weather elements over complex mountainous regions by state-of-the-art numerical weather prediction (NWP) models, so statistical relationships are developed between a variable, which is to be predicted at the location of interest (predictand) and nearby observed values of surface and upper-air weather elements (predictors).

\footnotetext{
Author's Address

College of ForestryUttarakhand University of Horticulture \& Forestry Ranichauri Campus, Tehri Garhwal-249199 (Uttarakhand)

E-mail: drrgupadhyay11@gmail.com
}

Uttarakhand state has varied topographical features ranging from high hills to Tarai thereby the state experiences different climatic conditions. The plains and valleys are hotter in summers as compared to hills. The valleys are cooler in winters. The region has wide variations in topography as well as weather. Agriculture is mainly rainfed. Major problems are low temperature, erratic distribution of rainfall and short growing season. The major crops of the region are small millets, under-utilized crops like amaranth, rice bean, buck wheat etc. Irrigated rice is grown predominantly in valleys and upland rice is cultivated at higher elevations. The mid hill regions of the state supports off season vegetable crops (Murty et al. 2002). The temperatures fall rapidly during October and drops down to subzero temperature during winter in the region. The fall in temperature greatly influences the crop growth and agricultural production. In mid Himalayan region during grain filling stage of amaranth, even $1{ }^{\circ} \mathrm{C}$ drop in minimum temperature in October, drastic yield reduction was observed (Murty and Singh, 2002). 
The diurnal temperature variations in the region are small therefore, temperature plays and important role in crop production. Hence an attempt is made to study the temperature variation in mid Himalayas region. Such studies have attempted by different authors in different parts of the India (Pant and Hingane, 1988 Jain and Dubey, 1991, Samui and Gupta, 1992, Attri et al. 1995).

\section{Material and Methods}

The daily meteorological data of Ranichauri (longitude of $78^{\circ} 02^{\prime} \mathrm{E}$, (latitude of $30^{\circ} 15, \mathrm{~N}$ and an altitude of $1950 \mathrm{~m} \mathrm{msl}$ ) in mid Himalayan region of Uttarakhand for the period 2003-2012 was utilized for the study. The daily maximum and minimum temperatures were converted to monthly, seasonal and yearly average for statistical analysis. The temperature trends were determined using 2year moving averages. The soil moisture percentage measured at periodic interval of 15 days during the crop season .The growing degree days (GDD) and actual evapotranspiration (AEt) values derived from Thornthwaite method during different Phenological stages of crop growth and their dates of occurrence. The total dry matter $\left(\mathrm{g} / \mathrm{m}^{2}\right)$ and plant height $(\mathrm{cm})$ were recorded at various growth stages of crop. The yield and yield contributing characters viz, 1000 seed weight, number of plants $/ \mathrm{m}^{2}$, number of spikelet/panicle were recorded at the time of harvesting.

\section{Results and Discussion}

The trend and moving average of both maximum and minimum temperatures were calculated and the results are as follows: The maximum and minimum temperature trends are presented in Table 1. The trend of minimum temperature from 2003-2012 indicates very little increasing trend while the moving average trends show slight decline in temperatures. Similar results were reported by Ram sing (2003). He was observed that in maximum number of months the minimum temperature departure was near normal followed by decrease in minimum temperature at Hisar. The maximum temperature (Fig.1) trend was decreased over the period of study. Compared to the minimum temperature the deviation of maximum temperature was decreased over the period of study. Compared to the minimum temperature the deviation of maximum temperature was less. The data is almost following the trend line. The trend line equations are presented in Fig. 1.

The seasonal analysis indicates that the minimum temperature shows an increasing trend during, winter and post monsoon seasons while a sharp decline was observed during summer season. The temperature variation was more in rainy season and less in post rainy season. The standard deviation (SD) and Mean of maximum and minimum temperatures are presented in Table 2. The soil moisture percentage measured at periodic interval of 15 days presented in table 3. The soil moisture varied between 7.9 and $29.13 \%$ across different depths during the crop season. The growing degree days (GDD) and actual evapotranspiration (AEt) values derived from Thornthwaite method during different phonological stages of crop growth and their dates of occurrence are given in table 4.

Though wheat crop were sown on three different dates with an interval of 20 days, the crop sown on $\mathrm{I}^{\text {st }}, \mathrm{II}^{\mathrm{nd}}$ and $\mathrm{III}^{\text {rd }}$ dates germinated on $26 / 11 / 2012$, $19 / 12 / 2012 \& 06 / 01 / 2013$ on receipt of rains of 2.4 $\mathrm{mm}$ on $22 / 10 / 2011$ and $6.1 \mathrm{~mm}$ on $9 \& 10^{\text {th }} \mathrm{Dec}$ 2011. Due to very low temperature prevailed in the region during winter season coupled with dew \& no rainfall from October 23, 2011 to Dec 08, 2011, the germination and other phenological stages occurred on different dates in I ${ }^{\text {st }}$, II $^{\text {nd }}$ and III $^{\text {rd }}$ date of sowing during the crop season. The growing degree days and actual evapotranspiration decreased as sowings were delayed. The growing degree days varied between 1352.95 \& 1376.10 across the dates of sowing. The total dry matter (TDM) during different growth stages is presented in table 5. The total dry matter varied between 132.341 and $579.136 \mathrm{~g} / \mathrm{m}^{2}$ across dates of sowing and varieties. With first date of sowing, both the varieties produced highest biomass of 594.331 $\mathrm{g} / \mathrm{m}^{2}, 570.778 \mathrm{~g} / \mathrm{m}^{2}$ respectively. The total dry matter and growing degree days were correlated. The correlation was found to be significant $(r=$ 0.919). The plant height measured during different growth stages is presented in table 6 . The highest plant height of $88.8 \mathrm{~cm}$ and $74.2 \mathrm{~cm}$ was observed with Second date of sowing in case of varieties UP1109 and Sonalika with $\mathrm{I}^{\text {st }}$ date of sowing respectively. However, the plant height was decreased as the sowings were delayed. A correlation was found between plant height and growing degree days during different growth 
stages. The correlation was found to be significant Similarly, the number of grains $/ \mathrm{m}^{2}$ varied between $(\mathrm{r}=0.971)$. The plant characteristics like 1000 seed 5242 and 7162. The 1000 seed weight was around weight, number of plants $/ \mathrm{m}^{2}$, number of $40.00 \mathrm{~g}$ across varieties and dates of sowing. The spikelet/panicle etc. are presented in table 7. The seed yield as influenced by different dates of average number of spikelet/panicle was 38 in both sowing and varieties is presented in table 7 . The the varieties. The number of plants/ $\mathrm{m}^{2}$ was 185 , highest seed yield of $1782.48 \mathrm{~kg} / \mathrm{ha}$ was recorded 179 and 168 in variety UP-1109 with respect to $\mathrm{I}^{\text {st }}$, with second date of sowing. Across dates of $\mathrm{II}^{\text {nd }}$ and III $^{\text {rd }}$ date of sowing respectively. The sowing, variety UP-1109 produced $1782.48 \mathrm{~kg} / \mathrm{ha}$ number of panicles $/ \mathrm{m}^{2}$ varied from 144 to 162 . while variety Sonalika produced $1489.55 \mathrm{~kg} / \mathrm{ha}$.

Table: 1: Seasonal Variation of Temperature ${ }^{\circ} \mathrm{C}$ (Maximum and Minimum)

\begin{tabular}{|l|l|l|l|l|l|l|l|l|l|}
\hline \multirow{2}{*}{ S. No } & \multirow{2}{*}{ Period } & \multicolumn{2}{|l|}{$\begin{array}{l}\text { \% Winter } \\
\text { (Dec-Feb) }\end{array}$} & \multicolumn{2}{l|}{$\begin{array}{l}\text { \% Summer } \\
\text { (Mar-May) }\end{array}$} & \multicolumn{2}{l}{$\begin{array}{l}\text { \% Monsoon } \\
\text { (Jun-Sep) }\end{array}$} & \multicolumn{2}{l}{$\begin{array}{l}\text { \% Post Monsoon } \\
\text { (Oct-Nov) }\end{array}$} \\
\cline { 3 - 10 } & & $\begin{array}{l}\text { Max. } \\
\text { Temp }\end{array}$ & $\begin{array}{l}\text { Mini. } \\
\text { Temp }\end{array}$ & $\begin{array}{l}\text { Max. } \\
\text { Temp }\end{array}$ & $\begin{array}{l}\text { Mini. } \\
\text { Temp }\end{array}$ & $\begin{array}{l}\text { Max. } \\
\text { Temp }\end{array}$ & $\begin{array}{l}\text { Mini. } \\
\text { Temp }\end{array}$ & $\begin{array}{l}\text { Max. } \\
\text { Temp }\end{array}$ & $\begin{array}{l}\text { Mini. } \\
\text { Temp }\end{array}$ \\
\hline 1. & $\mathbf{2 0 0 3 - 0 4}$ & 13.0 & 2.2 & 23.1 & 10.5 & 23.6 & 15.1 & 18.6 & 6.5 \\
\hline 2. & $\mathbf{2 0 0 5 - 0 6}$ & 15.0 & 3.7 & 22.1 & 9.9 & 23.9 & 15.5 & 19.5 & 7.9 \\
\hline 3. & $\mathbf{2 0 0 7 - 0 8}$ & 13.4 & 2.6 & 21.9 & 9.9 & 23.0 & 15.3 & 19.4 & 7.8 \\
\hline 4. & $\mathbf{2 0 0 9 - 1 0}$ & 14.4 & 3.7 & 23.4 & 11.5 & 23.6 & 15.9 & 19.3 & 8.0 \\
\hline 5. & $\mathbf{2 0 1 1 - 1 2}$ & 16.5 & 5.8 & 21.3 & 9.9 & 22.0 & 12.4 & 19.6 & 8.3 \\
\hline
\end{tabular}

Table: 2: Seasonal variation of Temperature ${ }^{\circ} \mathrm{C}$ (Maximum andMinimum)

\begin{tabular}{|l|c|c|c|c|}
\hline \multirow{2}{*}{ Seasons } & \multicolumn{4}{|c|}{ Temperature C } \\
\cline { 2 - 5 } & \multicolumn{2}{|c|}{ Maximum } & \multicolumn{2}{c|}{ Minimum } \\
\cline { 2 - 5 } & Mean & SD & Mean & SD \\
\hline Winter & 14.48 & 1.39 & 3.58 & 1.41 \\
Summer & 22.36 & 0.90 & 10.36 & 0.69 \\
Rainy & 23.22 & 0.74 & 14.48 & 1.41 \\
Post rainy & 19.28 & 0.41 & 7.70 & 0.68 \\
\hline
\end{tabular}

\section{Trend of Maximum Temperature (2003-2012)}

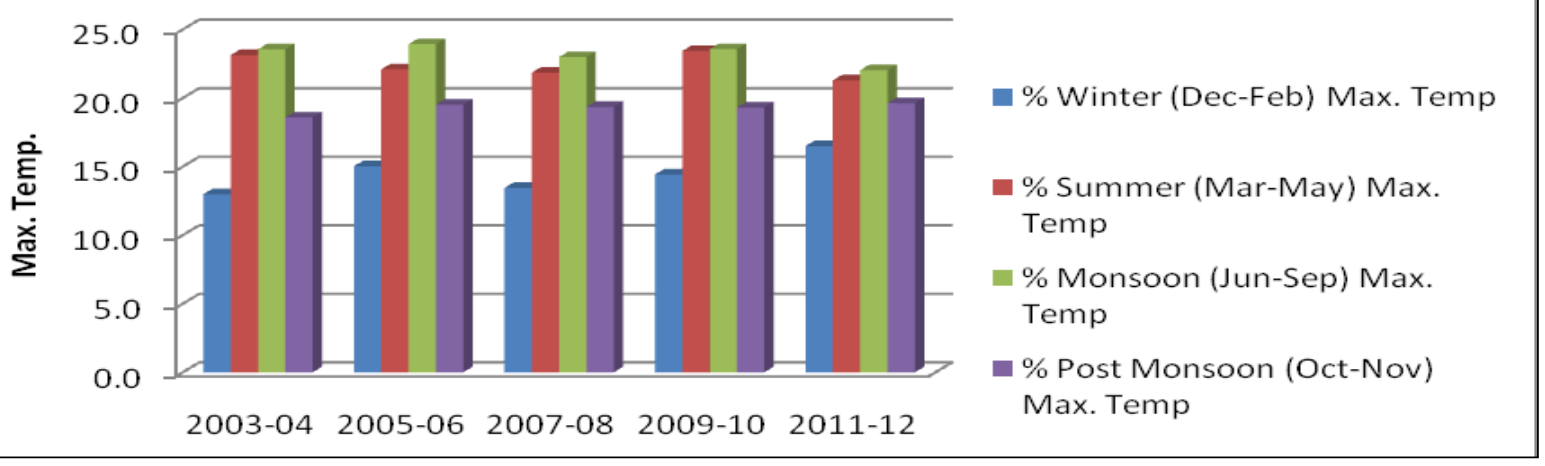

Fig. 1: Showing trend of maximum temperature 
Fig. 2: Showing ten years moving average
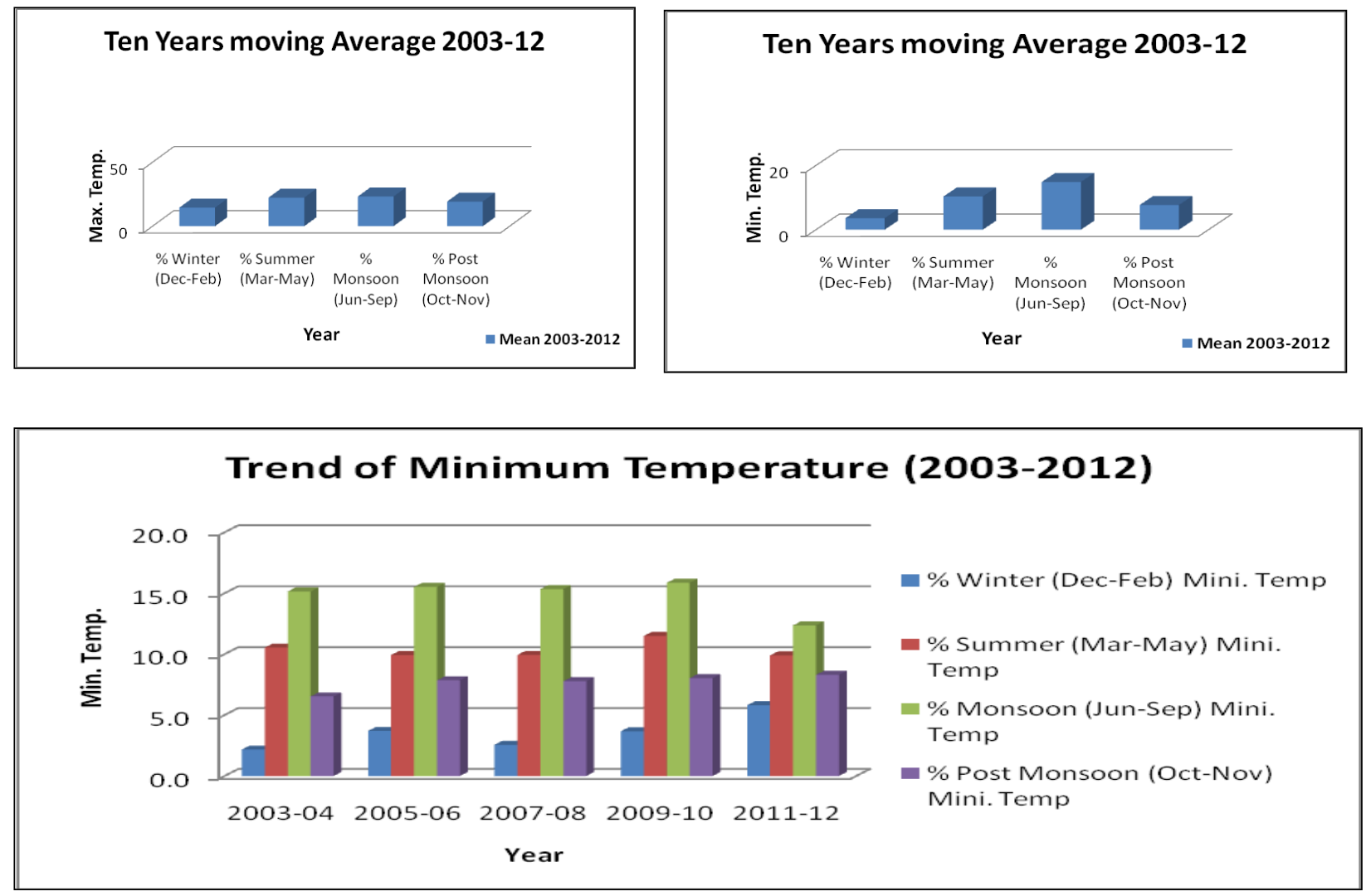

Fig. 3: Showing trend of minimum temperature

Table 3: Soil moisture (\%) measured at different growth stages of crop

\begin{tabular}{|l|l|l|l|}
\hline \multirow{2}{*}{ Date } & \multicolumn{3}{|c|}{ Depth (cm) } \\
\cline { 2 - 4 } & $0-15$ & $15-30$ & $30-45$ \\
\hline 30.10 .12 & 16.6 & 28.7 & 29.1 \\
\hline 20.11 .12 & \multicolumn{1}{|c|}{14.1} & 16.5 & 15.8 \\
\hline 10.11 .12 & 17.6 & 18.6 & 20.1 \\
\hline 26.12 .12 & 17.0 & 14.8 & 19.8 \\
\hline 11.01 .12 & 22.6 & 24.4 & 21.9 \\
\hline 29.01 .13 & 22.1 & 22.1 & 21.65 \\
\hline 10.02 .13 & 26.7 & 25.1 & 27.9 \\
\hline 25.02 .13 & 18.9 & 22.7 & 24.6 \\
\hline 10.03 .13 & 21.4 & 24.8 & 22.6 \\
\hline 25.03 .13 & 19.3 & 21.4 & 20.5 \\
\hline 10.04 .13 & 10.6 & 12.8 & 16.9 \\
\hline 25.04 .13 & 12.3 & 14.5 & 14.9 \\
\hline 10.05 .13 & 7.9 & 11.1 & 12.4 \\
\hline
\end{tabular}


Table 4: GDD at different Phenological stages and date of its occurrence

\begin{tabular}{|ll|c|c|}
\hline \multicolumn{1}{|l|}{ Phenological Stage } & Date of occurrence & Growing degree days \\
\hline Germination & D1 & 26.12 .12 & 313.45 \\
& D2 & 28.12 .12 & 168.00 \\
& D3 & 01.01 .13 & 66.85 \\
\hline CRI Stage & D1 & 10.02 .13 & 384.60 \\
& D2 & 25.02 .13 & 276.55 \\
& D3 & 11.03 .13 & 275.85 \\
\hline Tillering & D1 & 12.02 .13 & 395.70 \\
& D2 & 28.02 .13 & 295.65 \\
& D3 & 15.03 .13 & 308.65 \\
\hline Jointing & D1 & 26.02 .13 & 431.70 \\
& D2 & 10.03 .13 & 377.85 \\
& D3 & 20.03 .13 & 344.90 \\
\hline \multirow{6}{*}{ Anthesis } & D1 & 11.04 .13 & 814.45 \\
& D2 & 14.04 .13 & 700.60 \\
& D3 & 17.04 .13 & 624.40 \\
\hline Milking & D1 & 23.04 .13 & 950.75 \\
& D2 & 26.05 .13 & 1280.95 \\
& D3 & 01.05 .13 & 791.85 \\
\hline Harvesting & D1 & 23.05 .13 & 1376.10 \\
& D2 & 30.05 .13 & 1352.95 \\
& D3 & 07.06 .13 & 1366.75 \\
\hline
\end{tabular}

Table 5: Total dry matter $\left(\mathrm{g} / \mathrm{m}^{2}\right)$ during different growth stages of crop

\begin{tabular}{|l|c|c|c|c|}
\hline & \multicolumn{4}{|c|}{ Dates of Sampling } \\
\cline { 2 - 5 } & $\mathbf{3 0 . 0 3 . 1 2}$ & $\mathbf{1 5 . 0 4 . 1 2}$ & $\mathbf{3 0 . 0 4 . 1 2}$ & $\mathbf{1 5 . 0 5 . 1 2}$ \\
\hline I Date of Sowing & 226.113 & 318.161 & 430.281 & 579.136 \\
\hline UP - 1109 & 190.364 & 273.534 & 410.127 & 574.469 \\
\hline Sonalika & 276.610 & 419.193 & 480.185 \\
\hline II Date of Sowing & 191.361 & 279.130 & 454.567 & 540.237 \\
\hline UP - 1109 & 189.183 & 284.543 & 401.141 & 568.326 \\
\hline Sonalika & 176.564 & 229.981 & 387.126 & 516.617 \\
\hline III Date of Sowing
\end{tabular}

The significant difference in seed yield was observed due to different dates of sowing, the first date of sowing produced highest yield in case of UP-1109 while, Sonalika produce the highest yield in second date of sowing. Though, the yields due to varieties and interaction between dates \& varieties were not significant. The performance of wheat during rabi season 2012-13 was found to be satisfactory with second and second dates of sowing only due to even distribution of rainfall during the crop season, even then the amount of rainfall was below normal the requirement of the crop/normal rainfall throughout the season. 
Upadhyay and Negi

Table 6: Plant height $(\mathrm{cm})$ measured during different growth stages of crop

\begin{tabular}{|l|c|c|c|c|}
\hline \multirow{2}{*}{ Treatments } & \multicolumn{4}{|c|}{ Dates of Sampling } \\
\cline { 2 - 5 } & $\mathbf{3 0 . 0 3 . 1 2}$ & $\mathbf{1 5 . 0 4 . 1 2}$ & $\mathbf{3 0 . 0 4 . 1 2}$ & $\mathbf{1 5 . 0 5 . 1 2}$ \\
\hline I Date of Sowing & 46.6 & 58.5 & 76.7 & 81.1 \\
\hline UP - 1109 & 44.4 & 54.3 & 73.0 & 85.2 \\
\hline Sonalika & 35.0 & 52.2 & 62.4 & 88.8 \\
\hline II Date of Sowing & 35.3 & 53.9 & 65.6 & 83.5 \\
\hline UP - 1109 & 32.1 & 43.1 & 54.5 & 76.1 \\
\hline Sonalika & 30.6 & 41.6 & 52.2 & 74.2 \\
\hline III Date of Sowing & \multicolumn{5}{|l|}{} \\
\hline UP - 1109 & \multicolumn{5}{|l|}{} \\
\hline Sonalika &
\end{tabular}

Table 7: Yield and yield attributes of wheat

\begin{tabular}{|c|c|c|c|c|c|c|}
\hline Treatment & $\begin{array}{c}\text { No of } \\
\text { Spikelet/Panicle }\end{array}$ & $\begin{array}{l}\text { No of } \\
\text { Grain } / \mathbf{m}^{2}\end{array}$ & $\begin{array}{l}\text { No of } \\
\text { Panicle } / \mathbf{m}^{2}\end{array}$ & $\begin{array}{l}1000 \text { Seed } \\
\text { Weight }(g)\end{array}$ & $\begin{array}{l}\text { No of } \\
\text { Plant } / \mathrm{m}^{2}\end{array}$ & $\begin{array}{c}\text { Mean } \\
\text { Yield } \\
\text { (kg/ha) }\end{array}$ \\
\hline \multicolumn{7}{|c|}{ I Date of Sowing } \\
\hline $\mathrm{UP}-1109$ & 41 & 5940 & 156 & 41.336 & 179 & 1729.13 \\
\hline Sonalika & 38 & 5836 & 158 & 39.632 & 177 & 1308.15 \\
\hline \multicolumn{7}{|c|}{ II Date of Sowing } \\
\hline UP - 1109 & 43 & 7162 & 162 & 41.963 & 185 & 1782.48 \\
\hline Sonalika & 38 & 5880 & 158 & 40.113 & 176 & 1489.55 \\
\hline \multicolumn{7}{|c|}{ III Date of Sowing } \\
\hline UP - 1109 & 36 & 5368 & 149 & 37.194 & 168 & 1579.20 \\
\hline Sonalika & 35 & 5242 & 144 & 38.380 & 169 & 1160.80 \\
\hline
\end{tabular}

Therefore, early and normal sowing of wheat crop is recommended under rainfed condition in mid Himalayan region. Late sowing of the crop is not recommended since it germinates late on receipt of rainfall followed by low temperature in Jan \& Feb months and also low rainfall in March/April month coincides with peak growth period of the crop.

Early, normal and late sown crops in the Kharif season germinated well and thereafter the crops suffered slightly due to the excess moisture and high humidity prevailed in the region throughout the season due to the excess rainfall from July and August months coincides with grand growth stage. Thereafter seed setting stage of the most of the kharif crops, resulting into the performance of the kharif crops were not good and production below normal yields especially in underutilized crops. The performance of Rabi crops (2012-13) was in general not satisfactory due to dry condition attributed by low rainfall during Rabi season. However, the crops suffered from moisture stress during the terminal stages of the crop. The overall performance of rabi crops was satisfactory due to optimum temperature for proper growth, development, flowering, maturity and yield of wheat. From the above studies it can be concluded that the maximum temperature as shown decreasing trend while the minimum temperature is almost 
stable during the period of study at College of Forestry \& Hill Agriculture, Ranichauri. The seasonal variation of minimum temperature has

\section{References}

Atztri, S.D. Pandys, A.B and Dubey, D.P 1995 Forecasting of minimum temperature over gangtok. Mausam 46(1):63-68.

Jain, C.K and Dubey D.P.1991 Variation of minimum temperature over Bhopal. Vayumandal. 20(3-4): 115-119.

Murty, N.S. and Singh, R.K 2000. Studies on crop weather relationships of grain amaranth in central Himalayan region of U.P. Proceedings of international conference on managing natural resources for sustainable agricultural production in $21^{\text {st }}$ century, natural resources (weather and climate ) Vol. 2:589-591.

Murty, N.S. Gaira, K.S. and Singh, R.K. 2004.Temperature variation at Ranichauri in the mid Himalayan region of Uttarakhand; Journal of Agrometeorology Vol.6 (Sp. Issue, 2004): 227-232

Murty, N.S. Singh, R.K and Uniyal, S.P.2002. Studies on climate based vegetable crop rotation in the mid Himalayan region of Uttaranchal. Environment, energy indicated that the trends are increasing in all the seasons except rainy season.

and development, Ed. S.B. Singh, National Geographical Society of India, Publication No.44:91-96.

Pant, G.B and Hingane, L.S. 1988 Climatic changes in and around the Rajasthan desert during $20^{\text {th }}$ century. $J$. Climatology. 8: 391-410.

Pant, G.B., Rupa Kumar, K and borgaonkar,. H.P. 1999. Climate and its long term variability over the wetern Himalaya during the past two centuries. The Himalayan environment, Ed. S.K .dash and J.Bahadur, New age international (P) Limited, PP: 171-184.

Ram Singh., 2003. A climatological study on minimum temperature at Hisar. J. Agromet. 5(1):124-128.

Samui, R.P. and Gupta, D.C.1992. Severe winter associated with cold waves at two hill stations in sikkim. Vayu Mandal. 22(1-2) : 52-56. 